\title{
Dialogue
}

http://journals.cambridge.org/DIA

Additional services for Dialogue:

DIALOGUE

Revue

canadienne de

Email alerts: $\underline{\text { Click here }}$

Subscriptions: $\underline{\text { Click here }}$

Commercial reprints: Click here

Terms of use : $\underline{\text { Click here }}$

\section{Marxism and Moralism}

\section{Evan Simpson}

Dialogue / Volume 29 / Issue 04 / September 1990, pp 583 - 588

DOI: 10.1017/S0012217300048289, Published online: 13 April 2010

Link to this article: http://journals.cambridge.org/ abstract S0012217300048289

How to cite this article:

Evan Simpson (1990). Marxism and Moralism. Dialogue, 29, pp 583-588 doi:10.1017/S0012217300048289

Request Permissions : $\underline{\text { Click here }}$ 


\title{
Marxism and Moralism*
}

\author{
EVAN SIMPSON Victoria University of Wellington
}

Moral philosophers continue to divide on the conundrum of Marx and morality - how a ferocious moral critic of nineteenth-century capitalism could also denounce morality as an ideological snare and delusion. In Marxism and the Moral Point of View, Kai Nielsen brings together many years of thought on both terms of the question, rightly seeking a balance between Marx's moralism and Marx's anti-moralism.

Marx's historical materialism poses a general problem for the validity of moral conceptions. This theory explains successive stages of civilization, or class society, as effects of developing productive forces. Each successive set of economic forces is favourable to the dominance of a particular social class, whose social control is reinforced by the dominant ideas of the epoch. Thus, Aristotle's notion of natural slaves justified the privileges of citizens in a society one or two steps removed from subsistence, while the notion of freedom of choice justifies the privileges of capital in a system of organization which responds to meeting wants. In retrospect we can always see such justifications of class relationships as reflections of a system of production rather than as defensible moral claims, so that fully understanding these justifications dissolves reasons for accepting them. In this way, historical materialism includes a sociology of moral beliefs which undermines them and explains why Marx could regard them as nonsense.

However, this description is too coarse to rule out the validity of any moral belief whatever. As Nielsen notes, the unacceptable beliefs are those whose function it is to disguise class interest as moral truth. It does not follow from the fact that certain conceptions of natural inferiority and individual freedom have this function that moral beliefs lacking this role also lack validity. We can, he says, identify many "moral truisms"' without pretending that there are eternal moral principles or supposing that moral ideas are dominant factors in epochal change (p. 3, 34, 132, 214, 233). This seems right. Since historical materialism is a theory of such change, we might expect it to have little to say about these truisms. To rule them out as nonsense 


\section{Dialogue}

would be to say much more than the theory warrants. While Marx's thesis is not simply or primarily moral (p. 1,14 ), then, it seems fully consistent with maintaining that "ordinary human feelings" and "commonsensical moral beliefs" are valid (p. 33), that these beliefs, unlike ideololgical beliefs, are not inherently conservative (cf. p. 122), and that they will survive class society (p. 265). The ideology of freedom and equality which helps to sustain capitalism will disappear, but freedom and equality are clearly good things when understood as conditions of self-respect and mature friendship rather than as myths that sustain the wage relationship. They belong to nonpolitical morality and can be expected to remain in any post-political society.

Marxists need not hesitate, therefore, to recognize manifest moral truisms. Amongst the obvious goods Nielsen places health, pleasure, autonomy, satisfaction (p. 10); equality, fraternity, mutual respect (p. 33); selfrespect, happiness (p. 127); reciprocity, freedom (p. 200); and friendship (p. 267). There are equally obvious evils: suffering, degradation, servitude, powerlessness (p. 10); poverty, exploitation, and the crippling of human personality (p. 127). This is a mixed bag, but the various goods are, in Nielsen's view, united by a common property. Unlike ideological beliefs, these valid claims are not extinguished by the knowledge of the causes of our beliefs (p. 35, 146). They survive such tests as Nielsen's wide reflective equilibrium or Richard Brandt's cognitive psychotherapy.

This notion of moral truisms is much less perspicuous than it initially seems. In order to appreciate this, let us consider Nielsen's portrait of class society. Capitalist society in particular dehumanizes labour, causes suffering and degradation and undermines autonomy (p. 248). It is a contemporary truism, however, that labour today is in a very different situation from workers in England's satanic mills. If Marxism is to continue to be of interest it must accommodate this difference. In one way this is easy to do. We need only say of the relationship between labour and capital what Marx said of feudal relations in their heyday. The fight between the two great hostile camps of bourgeoisie and proletariat is in an unexpectedly hidden phase in which the "naked, shameless, direct, brutal exploitation" described in the Communist Manifesto has again been veiled by political illusions. We may then say that suffering and degradation continue to be experienced but go unrecognized (p. 165). As soon as we need to unmask exploitation, however, and convince people that - contrary to their own self-conceptions they are suffering and degraded, it becomes problematic how to construe the moral truisms.

Nielsen wants to avoid the paradox of viewing all thinking as ideologically distorted (p. 112), but false consciousness goes very deep if we can be mistaken about truistic goods and evils. If we want to avoid suffering and degradation in the abstract but do not recognize them in the concrete, it is not clear what we want exactly. Nielsen's ultimate ideal is for all persons to 
have as much as possible of whatever it is that they want (p. 213), but the ideal requires that these wants be adequately informed and reflectively tested. This makes the account suspiciously a priori in conception: if we fail to recognize the suffering and degradation postulated by the theory and therefore fail to rebel against them, we must not be adequately informed or reflective enough. The view becomes unfalsifiable rather than truistic. The appropriate response to this charge may be that wants are to be examined through a variety of empirical social theories, but if wants must pass this kind of test we are again remote from truisms.

Another dimension of the difficulty for moral truisms is evident in the claim that "the lives of more people become objectively better as we go through these epochal transformations [ancient, feudal, capitalist, socialist]" (p. 132). The standard of objectivity here is the set of possibilities, created by developing productive forces, for greater human flourishing and autonomy, but this is an ambiguous standard. It conflicts with familiar arguments about the alienation and meaninglessness typical of capitalistic society as evils outweighing the forms of well-being and autonomy the system provides. The gains our society has made in reducing disease, hunger, poverty and overwork have to be balanced against the losses: the banality of existence in technological societies, as conservatives may see it, the loss of "idyllic relations" as Marx and Engels saw it in the Manifesto, perhaps even "the crippling of human personality." If such gains are ambiguous, then moral truisms provide no criterion of moral progress. This would help to explain and support the view that Marx's analysis of capitalism does not include a system of moral evaluation with which to judge social systems. Nielsen therefore needs a better argument for his view that "more technically developed modes of production enable more human beings to more fully and more equitably satisfy their wants and needs and that gives us good reason to believe they are also ethically superior" (p. 144).

In spite of these difficulties, it is plausible to say that there are indeed moral truisms. They may include the existence of specifically human goods arising in the course of our biological evolution - such as the expressions of limited altruism we find in feelings of pity and love and the associated desires to relieve suffering and respect the interests of certain others. These truisms confirm that much suffering is evil, that some mutual respect is good. They do not express eternal moral principles or bolster classes, as Nielsen insists truisms should not (p. 148). They concern sub-political relationships which could occur in a classless society (p. 259). Because these relationships are compatible with partiality and exclusiveness, they suggest, as Nielsen does, that various forms of inequality and moral conflict might remain after class conflict ends (p. 219). Since these occur below the level of class relationships, Marxism needs to recognize a place for them, as Nielsen clearly does in a discussion of Sittlichkeit (p. 265-266). The fact remains that Marxism has little distinctive to say about them. Those who would 
understand them might better turn to left-communitarians like Charles Taylor and Michael Walzer, who are more interested in the everyday life-world than in the remoter class struggles which resist moral assessment.

The distinction between moral and class conflict supports a wider separation between Marxism and moralism than Nielsen is content to allow. This is perhaps clearest in his appeal for equality. Now, the notion of a class is notoriously ill-defined (p. 104), but whatever classes are, we can say of them at least that they have a strong impact on our wants (p. 209), and that their existence indicates a society lacking in equality in some dimension (p. 57, 72, 217). Given the presence of equality in Nielsen's table of truistic moral goods, it should not be a want produced by class relationships but one which would remain in classless society and provide a reason for seeking such a society now. It is not clear, though, that we do or will have this desire or what its object is exactly. As a result, it is also unclear whether the appeal for equality is a proper element of Marxism or an expression of an independent moral theory grafted onto Marxism.

In order to develop this issue and to understand modern class conflict in relation to moral conflict, we may start with the recognition that the capitalist system dissolves an important difference. Useless things become useful in virtue of a demand having been created for them. The system cannot distinguish the desires expected of people whose human capacities are fully developed from objects of arbitrary or manipulated choice. Because no felt oppression need result we cannot usefully characterize the situation in psychological terms or expect it to be translated into a social movement. For the same reason we cannot accurately portray labour as a cohesive group. The characterization must be more abstract. Social classes are, indeed, best viewed as abstractions, like logical classes, rather than as conscious entities.

The important markers of capitalist society are not population statistics (contrast Nielsen, p. 236) but the transfer of wealth from labour to capital, a system of production oriented to exchange values, the proliferation of useless and harmful products, and minimal social control over production. In this description of the elements of labour and capital we find no reference to individual inequalities of income and wealth, much less an indication that the inegalitarian features of the early capitalist system still figure as telling grounds for criticism. It is, in short, unclear that egalitarianism defines a central objective of Marxism.

Having said this, it must be acknowledged that people do value equality. We may see this in experiences of resentment, love and forms of respect for persons. These values, however, have to do with the microstructure of human affairs, with the relatively transparent life-world, rather than the macroscopic relations (such as the transfer of wealth between classes) which are identified with the aid of social theories. Such desires for equality have particular persons as their referents and seem peripheral to the appropriate objectives of socialism. As we have already noted, these wishes may occur in 
any social system. There will always be occasions for battles for equal rights and recognition, for these are matters of hermeneutical self-understanding rather than reflections of the forces of production.

The claims of equality are again pressing in the case of income and wealth, insofar as discrepancies in these means of autonomous action frustrate conditions of well-being. Nielsen is sensitive to this connection, referring to "a gestalt of freedom, equality, and reciprocity" (p. 200) in order to defend equality as an intrinsic good by its connection with other goods. It is unclear, however, that we need speak of a gestalt here. The argument that a measure of material equality is a condition of general well-being is very strong. It, too, can be established independently of Marxian social theory. Liberals like Rawls are entirely comfortable with it. For this reason there is no apparent reason for resorting to the obscurity of evaluative gestalts. Nielsen himself suggests as much when he speculates about the need to supplement communist ideals with egalitarian principles of distribution (p. 9293). Here we have distinction rather than gestalt.

These uncertainties and contrary directions are all too characteristic of the debate about Marxism and distributive justice. The issue cannot be fully canvassed here, but there is little hope of establishing the need for principles of justice in classless society. In a moment of carelessness, Nielsen denies that Marx "thought that the working class would not need principles of justice in the future communist society" (p. 186). Of course, there is no working class in classless society. More importantly, in classless society the specific problem to which, in the Marxian account, principles of distributive justice respond has been overcome. That problem is the justification of transfers of wealth from one class to another. It is possible (though optional) to think of this transfer as unjustified - no one has consented to it - and as such unjust; but where there are no classes between which such a transfer may occur no relevant subject of a Marxian justice remains. Differences of income and wealth may still occur between individuals, as they will wherever there are markets, but this does not reflect the kind of structural problem that is of primary interest to Marxism, which opposes the market system - the dominance of the market in human affairs.

Important issues for Marxists remain when structural questions have been sufficiently differentiated from moral ones. Among the most pressing is an account of socialism in which individual advantages are not capable of developing into structural ones, including an account of the role of exchange after class society. The vast social experiment now underway in the Soviet Union does not prove but strongly suggests that markets are essential features of well-functioning complex societies. How they may function under democratic control rather than through the invisible hand, or how they may be used as a means of exchange while stopping short of a market system, is among the most pressing questions for radical philosophers. Without a clear 
answer to this question, current developments may be convincingly portrayed as the rejection of socialism for capitalism.

To this uncertainty should be added an ambiguity in the notion of socialist or communist society. These expressions may refer to a classless society or to society characterized by solidarity and community. These are different concepts, but Nielsen connects them without much argument. In "a society which had ended class structures ... a sense of social solidarity and community would develop"' (p. 90). What justifies this expectation? In classless society the zoon politikon will still carry the burden of its biological heritage. Human beings may continue to divide into exclusive communities and competing clans unless prevented from doing so. To suppose instead that a society of friends will develop is to see complex and heterogeneous societies as communities writ large. This neglects the difference between motives which unite us in families, neighborhoods, civic associations and the like and those that divide us into diverse groups.

If, as suggested earlier, moral truisms and relationships are most clearly identifiable in the everyday world of human relationships, it is easy to understand Marxist moralism. One wants to overcome differences between communities and societies in order to give common moral beliefs a role in motivating the project of social change and even helping to advance it. But in spite of Nielsen's best efforts there is no clear evidence that the moral claims on which people agree favour any social system over others. The serious gap in our understanding of relationships between morally united communities and social systems warrants caution in conjoining Marxism with a moral point of view. Doing this may confuse loyalty to community with obligations to society in a picture of socialist consciousness which has no real coherence. It may therefore create obscurities which act as obstacles to social change rather than promoting it. Clarity and progress may be better served by recognizing that Marxists are as entitled as anyone else to deplore suffering and other evils while insisting that moralism is distinct from their social theory. ${ }^{1}$

\section{Notes}

* Kai Nielsen, Marxism and the Moral Point of View: Mortality, Ideology, and Historical Materialism (Boulder: Westview Press, 1989). Page references are to this work.

1 This discussion has benefited from responses by Kai Nielsen to an earlier version read on May 27, 1989, at the annual meetings of the Canadian Philosophical Association. It has also gained from the contribution of my co-symposiast, Derek Allen, and from suggestions by John McMurtry. 